\title{
EDITORIAL
}

\section{Tribute to Longtime Annals Managing Editor Claire Zimmerman}

\author{
Jobn P. Geyman, MD \\ Professor Emeritus of Family Medicine, University of Washington School of Medicine, Seattle, Washington
}

Ann Fam Med 2019;17:4. https://doi.org/10.1370/afm.2331.

$\mathrm{T}$ The retirement of Claire Zimmerman from her long career behind the scenes in family medicine publishing is an occasion to pay tribute to her dedication and skill.

Claire has worked with authors and contributed to the quality of 3 journals over 38 years. As the founding editor of The Journal of Family Practice, I had the privilege to work with her from 1980 to 1990 at the University of Washington, followed by another 13 years at The Journal of the American Board of Family Medicine. She then went on to serve as the inaugural managing editor of the Annals of Family Medicine from 2003 to 2013, after which she became the lead copy editor.

Over all these years, Claire has been one of the key people making these journals work. The publishing field has gone through big changes during those years, evolving from editing by paper and pencil, to peer review and editing by computer, online publishing, and working on articles through "Dropbox on the cloud" (about which I have no clue!).
In the early 1970s in the United States, there was little tradition of research and publishing of original work in family medicine, so there was a need to help these authors learn the skills of effective writing. Claire contributed to this effort by bringing authors along through her encouragement and skilled editing feedback. She was always there to help despite the pressures of publishing deadlines.

Family medicine is indebted to Claire. Thank you, Claire, for your long dedication to family medicine journal publishing over a remarkable 38-year career, and all the best in your next chapter.

To read or post commentaries in response to this article, see it online at http://www.AnnFamMed.org/content/17/1/4.

Key words: history of medicine; scholarly publishing

Submitted August 11, 2018; accepted August 20, 2018. 